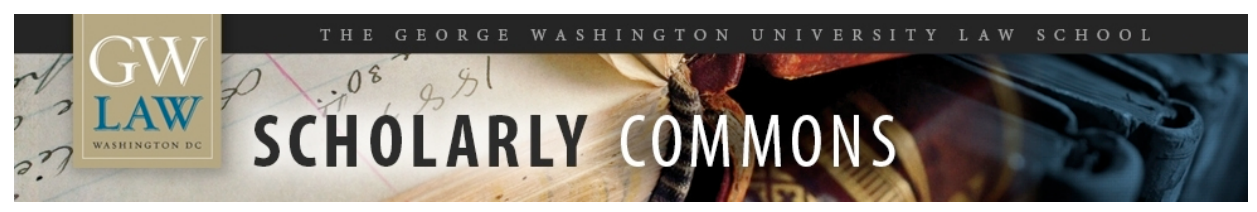

\title{
The Enforcement of United States Court Judgments in China: A Research Note
}

Donald C. Clarke

George Washington University Law School, dclarke@law.gwu.edu

Follow this and additional works at: https://scholarship.law.gwu.edu/faculty_publications

Part of the Law Commons

\section{Recommended Citation}

Clarke, Donald C., "The Enforcement of United States Court Judgments in China: A Research Note" (2004). GW Law Faculty Publications \& Other Works. 1067.

https://scholarship.law.gwu.edu/faculty_publications/1067

This Article is brought to you for free and open access by the Faculty Scholarship at Scholarly Commons. It has been accepted for inclusion in GW Law Faculty Publications \& Other Works by an authorized administrator of Scholarly Commons. For more information, please contact spagel@law.gwu.edu. 


\title{
The Enforcement of United States Court Judgments in China: A Research Note
}

\author{
Donald Clarke \\ George Washington University Law School \\ May 27, 2004
}

\begin{abstract}
Whether the judgments of United States courts can and will be enforced in China is a question that will be increasingly asked as economic ties grow between the two countries. At present, at least, the answer is straightforward: U.S. judgments will not be enforced. Chinese law requires the existence of a treaty or de facto reciprocity in order to enforce a foreign judgment; neither exists between the United States and China. Research reveals specific cases in which enforcement was refused and no cases in which enforcement was granted. Thus, the best alternative for litigants seeking the assistance of Chinese courts is to obtain an arbitration award in a New York Convention member country-China is a member itself-or to litigate in Chinese courts.
\end{abstract}

Whether the judgments of state and federal courts in the United States will, might, or can be enforced in China, both as a matter of Chinese law and in practice, is a question that occasionally crops up in litigation now and is bound to become more common as economic and other ties between the two countries grow denser. Unlike many questions about the Chinese legal system, however, this one can be answered with a fair degree of confidence both as to formal law and as to actual practice: almost certainly no, at least where a defendant is present and objecting. This research note sets forth the grounds for this conclusion.

The basic rule of Chinese law on the enforcement of foreign judgments is set forth in Articles 267 and 268 of the Civil Procedure Law. These provide in full as follows: ${ }^{1}$

Art. 267. Where it is necessary for the people's courts of the People's Republic of China to recognize and enforce legally effective judgments and rulings of foreign courts, a party may apply for recognition and enforcement directly to the Intermediate Level People's Court having

\footnotetext{
${ }^{1}$ The translation is my own.
} 
jurisdiction; a foreign court may also, in accordance with the provisions of an international treaty which the state of the foreign court and the People's Republic of China have concluded or to which they are parties, or in accordance with the principles of mutual benefit [reciprocity], request the people's court to recognize and enforce the judgment. Art. 268. The people's court shall, in accordance with the provisions of an international treaty which the state of the foreign court and the People's Republic of China have concluded or to which they are parties, or in accordance with the principles of mutual benefit [reciprocity], undertake a review of the legally effective foreign court judgment or ruling the recognition and enforcement of which is applied for or requested. If upon such review it concludes that such judgment does not violate the basic principles of the law of the People's Republic of China or state sovereignty, state security, or the public interest of society, it shall issue a ruling recognizing the judgment's validity; where enforcement is necessary, it shall issue an order for enforcement and enforce the judgment in accordance with the provisions of this Law. Where to do so would violate the basic principles of the law of the People's Republic of China or state sovereignty, state security, or the public interest of society, the court shall not grant recognition and enforcement.

In brief, Chinese law requires that there exist a treaty or reciprocity between the foreign state and China in order for a foreign judgment to be enforced.

At present there exists no treaty between the United States and China obligating China to enforce U.S. judgments, and I do not believe that a Chinese court would enforce a U.S. judgment on any other grounds, such as the existence of reciprocity. 
First, reciprocity does not in fact appear to exist. My research has failed to uncover a single case in which U.S. courts have enforced Chinese court judgments without inquiring into the underlying merits of the dispute.

Second, Chinese courts do not believe that reciprocity exists sufficient to support the enforcement of a U.S. court judgment. My research has found no cases in which a U.S. court judgment has been enforced on any grounds.

Third, the recognition and enforcement in China of foreign court judgments from any country—not just the United States-is extremely rare and occurs only in special circumstances. I have found three cases from the post-Mao era (i.e., the era to which the current legal system may be said to belong) in which a foreign judgment was recognized. All three cases involved foreign divorce proceedings between Chinese citizens, at least one of whom was living overseas. More importantly, none of the three was contested. In each case, both parties requested the Chinese court to recognize the divorce. Finally, none of the cases actually required the courts to enforce anything. They were asked merely to confirm the validity in China of the divorce decree, thus allowing the party resident in China to re-marry without having to initiate separate divorce proceedings in China. ${ }^{2}$

The only report of a case I have found where the enforcement of a foreign judgment might have been contested was one from the 1950s, when China and the U.S.S.R. had close and friendly relations. In that case, despite the absence of a treaty or a practice of reciprocity, China and the U.S.S.R. agreed through diplomatic channels that Chinese courts would enforce a U.S.S.R. judgment for child support against a Soviet

2 See Wang Lijian Case (No. 413), in 2 Renmin Fayuan AnLi XuAN -- Minshi JuAN [Selected Cases from the People's Courts-Civil Volume] 2027 (Zuigao Renmin Fayuan Zhongguo Yingyong Faxue Yanjiusuo [Supreme People's Court Institute for Practical Legal Research] ed., 2000); Jiang Xiaomin Case (No. 416), in id., at 2036; Li Geng Case (No. 216), in id., at 2030; also reported in Du XINLI, Guoji Sifa JiaOxue AnLi [Cases for the Study of International Private Law] 350-51 (1999). 
citizen living in China. ${ }^{3}$ The same source also mentions, without any details, the enforcement of an East German judgment; ${ }^{4}$ I do not know whether that was contested or not, or what the subject matter was. As these cases apparently had no impact on Chinese nationals, date from a completely different era in Chinese history, and involve political issues, they have little if any contemporary relevance.

By contrast, there is a modern case in which enforcement of a foreign judgment was refused. In 1994, the Dalian Intermediate Level People's Court considered the application of a Japanese national for the enforcement of a Japanese court judgment against another Japanese national. ${ }^{5}$ That judgment called for the defendant to transfer its equity interest in a Chinese company to the plaintiff ${ }^{6}$ in satisfaction of a debt. The Dalian court rejected the application, finding that neither a treaty nor reciprocity existed between China and Japan.

${ }^{3}$ See Yuan Chengdi, Guoji Sifa Yuanli [Principles of International Private Law] 368 (2003).

${ }^{4}$ See id.

${ }^{5}$ See Riben gongmin Wuwei Huang shenqing Zhongguo fayuan chengren he zhixing Riben fayuan panjue an [The Case of the Application of Japanese Citizen Gomi Akira to a Chinese Court for the Recognition and Enforcement of a Japanese Court Judgment], Zuigao Renmin Fayuan Gongbao [Supreme People's Court Gazette], No. 1, Mar. 20, 1996, at 29.

${ }^{6}$ This is my best understanding of what the judgment called for. The case report states that the judgment named the Chinese company as a third party and instructed it to transfer to the plaintiff the defendant's investment in it of RMB 4.85 million yuan. This may mean that the judgment purported to order the Chinese company in effect to redeem some or all of the defendant's equity share at the stated price and to pay the money to the plaintiff; it may also mean that the judgment purported to order the Chinese company to transfer to the plaintiff's name some or all of the defendant's equity share in the company represented by its original investment of RMB 4.85 million yuan. 
I have found only two cases in which the enforcement of a U.S. court judgment was sought in China. In both cases, the applicant was unsuccessful. In 1967, the Yantai Municipal People's Court rejected an application to recognize and enforce a divorce judgment from a U.S. court. ${ }^{7}$ In 1985, the Supreme People's Court issued a directive to the Shanghai Higher-Level People's Court (one level below the Supreme People's Court) instructing it not to recognize a U.S. divorce judgment, but instead to consider the case anew. ${ }^{8}$

In short, there is to date no evidence suggesting that a Chinese court would enforce the judgment of a United States court, and considerable evidence suggesting it would not. Parties seeking the assistance of Chinese courts in their disputes should either seek arbitration-arbitration awards from New York Convention member countries are enforceable in China-or litigate in China. ${ }^{9}$

\footnotetext{
7 See Li Wang, Guoji Susong Jinghe [Competition and Cooperation in
} International Litigation] 240 (2002). I do not believe that this case has any contemporary significance-it occurred at the height of the Cultural Revolution-and include it only for the sake of completeness.

${ }^{8}$ See Zuigao renmin fayuan guanyu lü-Mei huaqiao Zhang Xuefen xianhou xiang woguo fayuan he Meiguo fayuan qisu lihun Meiguo fayuan yi panjue lihun woguo fayuan shifou ke zai zuo panjue wenti de pifu [Reply of the Supreme People's Court on the Question of Whether Chinese Courts May Make an Additional Judgment Where Zhang Xuefen, an Overseas Chinese Resident in America, Has Successively Brought Divorce Actions in Chinese and American Courts and the American Court Has Already Made a Divorce Judgment], Sept. 19, 1985, available at www.chinalawinfo.com. This document is also discussed in LI WANG, supra note 7, at 240.

${ }^{9}$ See generally Donald C. Clarke \& Angela H. Davis, Dispute Resolution in China: The Arbitration Option, in CHINA 2000: EMERGING INVESTMENT, FUNDING AND ADVISORY Opportunities for A New CHINA 151-162 (Asia Law and Practice ed., 1999). 